\title{
HIV-associated tuberculous lymphadenitis: the importance of polymerase chain reaction (PCR) as a complementary tool for the diagnosis of tuberculosis - a study of 104 patients
} Linfadenite tuberculosa associada ao HIV: a importância da reação em cadeia de polimerase (PCR) como ferramenta complementar para o diagnóstico da tuberculose - estudo de 104 pacientes

Marcio Valle Cortez ${ }^{1}$

José Ribamar de Araújo ${ }^{4}$

Luis Carlos de Lima Ferreira ${ }^{6}$

\author{
Cintia Mara Costa de Oliveira ${ }^{2}$ \\ Bruna Backsmann Braga ${ }^{5}$ \\ Milton Ozório Moraes
}

\author{
Rossicléia Lins Monte ${ }^{3}$ \\ Débora Zotteli dos Reis ${ }^{5}$ \\ Sinésio Talhari ${ }^{8}$
}

\begin{abstract}
BACKGROUND: Lymphadenitis is common in HIV-positive patients. Diagnosis of the infections associated with this condition is complex, particularly in the case of tuberculosis. Rapid and specific detection of Mycobacterium tuberculosis (M. tuberculosis) is fundamental in ensuring adequate treatment. In addition, frequent causes of lymphadenitis such as those associated with lymphoma and histoplasmosis, among others, must be eliminated as possible causes.

Овјестіves: To evaluate the accuracy of polymerase chain reaction as a tool for the diagnosis of lymphadenitis resulting from $M$. tuberculosis.

Methods: In this study, a protocol was developed using the following procedures: direct microscopy using Ziehl-Neelsen staining, culture in Lowenstein-Jensen medium, histology and polymerase chain reaction.

Results: A total of 104 patients were included in the study. According to histopathology, 38 patients (36\%) were found to have nonspecific chronic lymphadenitis, 27 (26\%) had tuberculous lymphadenitis, 11 patients (10.5\%) had lymphoma and 9 (8.7\%) had histoplasmosis. When Lowenstein-Jensen culture was performed, positive tests for tuberculous lymphadenitis increased by $30 \%$. With polymerase chain reaction, $M$. tuberculosis DNA was detected in 6 out of 38 samples of non-specific chronic lymphadenitis. Three of these patients were followed up, developed symptoms of tuberculosis and were cured following specific treatment.

Conclusion: The data obtained in this study suggest that all cases of lymphadenopathies should be submitted to histopathology, Lowenstein-Jensen or Ogawa culture and polymerase chain reaction. Polymerase chain reaction may prove to be useful in providing an early and accurate detection of cases of extrapulmonary tuberculosis in HIV-positive patients with lymphadenopathies, avoiding empirical treatment and the possible development of resistant strains.
\end{abstract}

Palavras-chave: HIV; Infecções oportunistas relacionadas com a AIDS; Tuberculose; Tuberculose dos linfonodos

Resumo: Fundamentos: A linfadenite é comum em pacientes HIV-positivos. O diagnóstico das infecções associadas a essa condição é complexo, especialmente em relação à tuberculose. A detecção rápida e específica do Mycobacterium tuberculosis (M. tuberculosis) é essencial para o tratamento adequado. Além disso, frequentes causas de linfadenites tais como as relacionadas a linfoma, histoplasmose, e outras, devem ser afastadas.

OвJетіvos: Avaliar a importância da biópsia cirúrgica excisional das linfadenites e realização dos exames histopatológicos, exames baciloscópicos (Ziehl-Neelsen), cultura (Lowenstein-Jensen) e reação em cadeia da polimerase (PCR) com finalidade diagnostica

MÉTODOs: Desenvolveu-se um protocolo para biópsias excisionais de linfonodos, adotando-se os seguintes procedimentos: exame direto de esfregaços corados pelo método de Ziehl-Neelsen, cultura em meio de Lowenstein-Jensen, exame anátomo-patológico e PCR. Resultados: Ao todo foram incluídos 104 pacientes, e o exame histopatológico evidenciou 36\% ( $\mathrm{n}=38$ pacientes) de casos de linfadenite crônica inespecífica, $26 \%(\mathrm{n}=27)$ de linfadenite tuberculosa, 10,5\% $(\mathrm{n}=11)$ de linfoma e 8,7\% (n=9) de histoplasmose. Através da cultura no meio de Lowenstein-Jensen, os casos positivos para linfadenite tuberculosa aumentaram para 30\%. A PCR detectou M. tuberculosis em 6 das 38 amostras de linfadenite crônica inespecífica. Três desses pacientes foram acompanhados, exibiram sintomas de tuberculose e foram curados após tratamento específico.

Conclusão: Os dados obtidos neste trabalho sugerem que em todos os casos de linfadenopatia deve-se realizar exame histopatológico, cultura em Lowenstein-Jensen ou Ogawa e reação em cadeia da polimerase. A reação em cadeia da polimerase pode ser útil na detecção precoce e acurada de casos de TB extrapulmonar nos pacientes HIV-positivos com linfadenopatias, evitando-se o uso de tratamentos empíricos e o eventual desenvolvimento de cepas resistentes.

Keywords: AIDS-related opportunistic infections; HIV; Tuberculosis; Tuberculosis, lymph node

Recebido em 03.11.2010.

Aprovado pelo Conselho Consultivo e aceito para publicação em 15.11.10.

* Study conducted at the Amazonas Foundation of Tropical Medicine (FMTAM), Manaus, Amazonas, Brazil.

Conflict of interest: None / Conflito de interesse: Nenbum

Financial funding / Suporte financeiro: Amazonas State Foundation for the Support of Research (FAPEAM)

Specialist in surgery of the digestive tract. Professor of Clinical Surgery, Nilton Lins University Center, Manaus, Amazonas, Brazil PhD. Investigator at the Amazonas Foundation of Tropical Medicine (FMTAM), Manaus, Amazonas, Brazil.

Master's degree. Investigator at the Amazonas Foundation of Tropical Medicine (FMTAM), Manaus, Amazonas, Brazil.

Master's degree. Investigator at the Amazonas Foundation of Tropical Medicine (FMTAM), Manaus, Amazonas, Brazil.

Master's degree. Pathologist at the Amazonas Foundation of Tropical Medicine (FM
Undergraduate student, Nilton Lins University Center, Manaus, Amazonas, Brazil.

PhD. Pathologist at the Amazonas Foundation of Tropical Medicine (FMTAM), Manaus, Amazonas, Brazil

PhD. Investigator at the Leprosy Laboratory, Oswaldo Cruz Institute, Oswaldo Cruz Foundation (FIOCRUZ), Rio de Janeiro, Brazil

PhD. Professor of Dermatology. Nilton Lins University.

(C)2011 by Anais Brasileiros de Dermatologia 


\section{INTRODUCTION}

Human immunodeficiency virus (HIV) infection progressing to AIDS is still considered a major public health concern worldwide. According to the most recent statistics from the Joint United Nations Program on HIV/AIDS (UNAIDS), approximately 33 million people are living with HIV, 67\% of whom live in sub-Saharan Africa. Despite greater knowledge and awareness, the HIV/AIDS pandemic continues unabated throughout all the regions of the world. One of the main problems of HIV infection is that various opportunistic pathogens and the development of malignancies may result in different diseases, with lymph node enlargement, lymphadenitis, being a very common symptom. ${ }^{1,2}$

Tuberculosis is one of the main causes of lymphadenitis in HIV-positive patients and the risk of extrapulmonary tuberculosis and mycobacteremia increases as immunosuppression advances, particularly in developing countries. ${ }^{3.5}$ It is estimated that around 500,000 TB deaths occur in HIV-positive individuals worldwide. ${ }^{6}$ In Brazil, 94,000 new cases of TB were estimated to have occurred in 2009, nearly 42 cases per 100,000 individuals. In the state of Amazonas and in the city of Manaus, this incidence is particularly high, with rates of 73.5 and 81.7 per 100,000 individuals, respectively, in $2006 .{ }^{7,8}$

Excisional lymph node biopsy, followed by histopathology, acid-fast staining and mycobacterial culture, is the diagnostic procedure of choice. Sensitivity with rapid direct microscopy is low and culture takes 3 to 6 weeks. Therefore, protocols designed to explore complementary diagnostic techniques for TB diagnosis are necessary, particularly in health settings in which the prevalence of HIV/TB co-infection is high. ${ }^{9}$ ${ }^{12}$ In this regard, in-house conventional polymerase chain reaction (PCR) based on amplifying the IS6110 insertion element can be used to amplify Mycobacterium tuberculosis (MTB) DNA, offering the potential of a sensitive, specific and rapid diagnostic tool for either ruling out or considering pulmonary or extra pulmonary tuberculosis. ${ }^{13-15}$

The present study was conducted in a hospital setting in the Amazonas Foundation of Tropical Medicine [Fundação de Medicina Tropical Amazonas (FMTAM)], where the incidence of both TB and HIV is high. A protocol was designed to investigate the effectiveness of combining PCR with histopathological examination, Ziehl-Neelsen staining and culture in Lowenstein-Jensen medium to diagnose TB using lymph node excisional biopsies.

\section{METHODS}

Patients

From March 2007 to March 2009, samples of
104 HIV-positive patients submitted to lymph node biopsy performed by the same surgeon at the Amazonas Foundation of Tropical Medicine, Manaus, Amazonas, Brazil, were evaluated to determine the etiology of the condition. All patients submitted to the procedure had been previously investigated by an infectious diseases specialist and no diagnosis had been reached. The study protocol was approved by the institution's internal review board (\#756-10) and all patients enrolled in the study signed an informed consent form.

\section{Surgical Technique}

All biopsies were performed in the surgical theater of the institute. Patients were placed in the supine position and antisepsis of the region in which the lymph node was located (cervical, inguinal or axillary) was performed. The surgical field was defined, local anesthesia was administered and a skin incision of approximately $3 \mathrm{~cm}$ was made. Subsequently, the subcutaneous tissue was dissected and the lymph node was repaired using 2.0 sutures to avoid excessive manipulation. After resection of the ganglion, the subcutaneous tissue was pulled together and closed using 3.0 nylon sutures. Each sample was divided into two, with one half being sent for histopathology, while the remaining half was divided into three equal parts and sent for PCR, Ziehl-Neelsen staining and microbiology.

\section{Histopathology}

Samples were fixed and immunostaining was performed as previously described ${ }^{16}$. Briefly, all samples were fixed in phosphate-buffered paraformaldehyde solution (4\%), embedded in paraffin and stained with hematoxylin-eosin (H\&E) and Wade, and subsequently, when necessary, with Wade Grocott, periodic acid-Schiff for granulomatous diseases. In certain cases, when lymphoma was suspected, immunohistochemistry was performed according to the technique defined by Dabbs et al. ${ }^{16,17}$

\section{Mycobacterial staining and culture}

A fragment of each tissue sample (lymph nodes) was stored in vials with sterile saline. For the primary isolation procedure, fragments were transferred to a sterile mortar containing $5 \mathrm{ml}$ of sterile saline and then macerated with the use of a pestle. The suspension obtained was transferred to a $50 \mathrm{ml}$ tube and centrifuged at $3,000 \mathrm{~g}$ for 15 minutes at $4^{\circ} \mathrm{C}$. The supernatant was discarded, but approximately $2 \mathrm{ml}$ of the resulting solution was used to re-suspend the pellet, and $200 \mathrm{ul}$ aliquots were plated in Lowenstein Jensen 
culture medium, incubated at $37{ }^{\circ} \mathrm{C}$ and observed weekly for a period of 60 days.

Slides for Ziehl-Neelsen staining were then prepared according to the Brazilian Ministry of Health guidelines. The niacin test was performed to identify M. tuberculosis in accordance with a recommendation contained in the Handbook of Tuberculosis Bacteriology. ${ }^{18,19}$

\section{Sample storage, DNA extraction and PCR}

The tissue samples were stored in $200 \mathrm{uL}$ of TE buffer. Extraction of mycobacterial DNA was performed using the QIAamp DNeasy Blood \& Tissue (QIAGEN) kit in accordance with the manufacturer's instructions. Polymerase chain reaction (PCR) was performed using primers that amplify a fragment of 123 bp of the IS 6110 region (sense: 5-CCT AGC GCG TAG GCG TCG G-3 and antisense: 5- CTC GTC CAG CGC CGC TTC GG-3). The cycling conditions were: $95{ }^{\circ} \mathrm{C}$ for 5 minutes followed by 35 cycles of $95{ }^{\circ} \mathrm{C}$ for 30 seconds, $60{ }^{\circ} \mathrm{C}$ for 1 minute and $72{ }^{\circ} \mathrm{C}$ for 30 seconds, and a final extension at $72{ }^{\circ} \mathrm{C}$ for 5 minutes (Mastercycler - EP Gradient $\mathrm{S}^{\circledR}$ Eppendorf). The PCR products were analyzed in $2 \%$ agarose gel stained with ethidium bromide, visualized in transluminator UV and photographed using a digital photo documentation system (T26M EasyDOC $100^{\circledast}$ BioAgency). All samples were tested for -actin to evaluate inhibition of the PCR reaction. Primers and conditions were used as follows. ${ }^{20}$ All samples tested positive at -actin PCR.

Culture samples were used to obtain positive controls. Three colonies were placed in a Falcon tube containing $5 \mathrm{~mL}$ of Tris- $\mathrm{HCl}$ buffer and inactivated by boiling for 10 minutes prior to extracting mycobacterial DNA as previously described.

\section{RESULTS}

\section{Patients' demographic data}

Over a two-year period, 104 HIV-positive patients were submitted to lymph node excisional biopsy at the Amazonas Foundation of Tropical Medicine. Of these, $77 \%$ (80 patients) were male and 23\% (24) female. The mean age of patients was 32 years (range 15-72 years) and the male to female ratio was 3.3 to 1 . The most common biopsy site was the cervical region $(72 \% ; n=75)$, followed by the inguinal region $(24 \%$; $\mathrm{n}=26)$, the axillary region $(1.9 \% ; \mathrm{n}=2)$ and the forearm $(0.9 \% ; n=1)$.

Table 1 shows the most common diagnosis defined at histopathology. As expected, the disease most commonly found was tuberculous lymphadenitis (26\%), although the majority of samples remained undiagnosed (nonspecific lymphadenitis, 36\%). The next most common diagnoses were Hodgkin's (5.7\%) and non-Hodgkin's lymphoma (4.8\%), histoplasmosis
(8.7\%) and Kaposi's sarcoma (2.8\%).

Samples were also processed for microbiological culture, staining for mycobacteria and PCR. This integrated approach makes it possible to fill in the gaps that exist in the different evaluation methods when each one is used individually. Table 2 shows the results of each method compared to PCR.

According to the diagnostic resources available, mycobacteria staining (Ziehl-Neelsen staining) resulted in positivity in 13 out of 104 cases (12.5\%). When positivity with PCR was compared with that achieved with mycobacteria staining (Ziehl-Neelsen-positive), 11 samples tested positive with both techniques (PCRpositive and Ziehl-Neelsen-positive). Two samples tested positive with Ziehl-Neelsen staining, but were negative according to PCR (Table 2). Sensitivity and specificity, therefore, were $84 \%$ and $81 \%$, respectively, although in a further analysis of these two samples, one case was found to consist of nontuberculous mycobacteria, as revealed by culture in LowensteinJensen medium, while the other consisted of a case of leprosy, as defined by histopathology (Table 3).

When tissue suspensions were cultured in Lowenstein-Jensen medium, 11 samples tested positive, these samples also being found to be positive by PCR. In addition, another 3 samples were found to be PCR-negative and Lowenstein-Jensen-positive, while 2 consisted of nontuberculous mycobacteria (NTM) (Mycobacterium sp.), which were also diagnosed as tuberculous lymphadenitis (Table 3). The remaining sample tested positive for $M$. tuberculosis in Lowenstein-Jensen culture and also tested positive for tuberculous lymphadenitis at histology (Table 3). Therefore, sensitivity and specificity were $78 \%$ and $81 \%$, respectively (Table 2 ). Nevertheless, in this case, analysis using other methods confirmed one falsenegative case at PCR. On the other hand, the other two PCR-negative cases (NTM in Lowenstein-Jensen culture and consistent with tuberculous lymphadenitis at histopathology) are very suggestive of false-positive results at histopathology.

In addition, 11 samples tested negative for $\mathrm{TB}$ at PCR and positive at histopathology (Table 2), resulting in poorer sensitivity (62\%) and better specificity (84\%). However, only three of these samples actually tested positive in culture in Lowenstein-Jensen medium for NTM (2) and MTB (1), as shown previously. All the other samples (8) tested negative with all the techniques used (Table 3). Conversely, 12 samples were PCR-positive but were found to be negative at histopathology. These PCR-positive results consisted of: one case of histoplasmosis, one case of lymphoma, three samples grown in Lowenstein-Jensen culture and six samples with a histological result compatible with non-specific lymphadenitis and one sample sug- 
TABLE 1: Main causes of lymphadenopathies in HIV-positive individuals according to histopathological diagnosis

\begin{tabular}{ll}
\hline Diagnosis & Number of patients $(\mathbf{n}=\mathbf{1 0 4})$ \\
\hline $\begin{array}{l}\text { Non-specific lymphadenitis (including dermatopathic and granulomatous hyperplasia, } \\
\text { and reactive follicular hyperplasia) }\end{array}$ & $38(36 \%)$ \\
Tuberculous lymphadenitis & $27(26 \%)$ \\
Histoplasmosis & $9(8.7 \%)$ \\
Hodgkin's lymphoma & $6(5.7 \%)$ \\
Non-Hodgkin's lymphoma & $5(4.8 \%)$ \\
Kaposi's Sarcoma & $3(2.8 \%)$ \\
Toxoplasmosis & $2(1.9 \%)$ \\
Others ${ }^{a}$ & $14(13.4 \%)$ \\
\hline
\end{tabular}

${ }^{a}$ Paracococcidioides, leprosy, mycobacterial lymphadenitis, inconclusive (no histological changes) neurofibroma, metastasis, and adenoma.

gestive of mycobacterial infection as $\mathrm{ZN}+$ that seems very likely as TB (Table 3 ).

Finally, a combined analysis was conducted, with a diagnosis of tuberculosis being made when positivity was found either in Lowenstein-Jensen culture or at histopathology. The results of this analysis show that 19 samples were PCR-positive, a result that was also confirmed with the other techniques used. On the other hand, nine samples were PCR-positive but negative in Lowenstein-Jensen culture and at histopathology. These nine samples would be classified as false-positive results (Table 4). Analyzing these results, 6 out of 9 samples were diagnosed as nonspecific lymphadenitis. The other three PCR-positive cases that could not be included as TB were suggestive of histoplasmosis, hyperplasia and lymphoma at histology, as described previously (Table 3). Overall, sensitivity was $63 \%$ and specificity $87 \%$.

\section{DISCUSSION}

Tuberculosis has increased dramatically since the advent of HIV infection, and extrapulmonary involvement may be found in over $50 \%$ of patients with concurrent AIDS and tuberculosis. These demo- graphic data are similar to findings reported from previous studies conducted in Brazil, but differ from data reported in the USA, where a higher prevalence was found among females. ${ }^{10,21}$ Extra-pulmonary TB is the principal cause of HIV-associated lymphadenitis, although rates vary in the different countries with different prevalence rates of TB, ranging from $30 \%$ to $80 \%$ of cases. ${ }^{22}$ In Brazil and India, rates of extra-pulmonary TB of around 30\% have been reported, which are in agreement with the findings of the present study. ${ }^{3}$ $5 ; 8$

The 104 samples analyzed in the present study were from patients in whom a diagnosis of tuberculosis could not be made using more conventional methods; i.e. x-ray, clinical findings and PPD were all inconclusive, a clear indication for performing lymph node resection for diagnostic purposes. Moreover, this protocol in which fresh lymph nodes were used provides new insights into the sensitivity and specificity for a conclusive diagnosis of TB in HIV patients with lymphadenitis. Along with the freshness of the samples, the use of concomitant classical ZiehlNeelsen staining, Lowenstein-Jensen culture and histopathological examination in addition to PCR, provi-

TABLE 2: Comparison of PCR positivity with different classic diagnostic procedures for tuberculosis (Ziehl-Neelsen staining, culture in Lowenstein-Jensen medium or histopathology) in HIV-positive patients with lymphadenitis

\begin{tabular}{|c|c|c|c|c|c|c|}
\hline & \multicolumn{2}{|c|}{$\begin{array}{l}\text { Mycobacteria staining } \\
\text { (Ziehl-Neelsen) }\end{array}$} & \multicolumn{2}{|c|}{$\begin{array}{l}\text { Culture } \\
\text { (Lowenstein-Jensen) }\end{array}$} & \multicolumn{2}{|c|}{ Histopathology } \\
\hline & Positive & Negative & Positive & Negative & Positive & Negative \\
\hline \multicolumn{7}{|l|}{ PCR } \\
\hline Positive & 11 & 17 & 11 & 17 & 18 & 12 \\
\hline Negative & 2 & 74 & 3 & 73 & 11 & 63 \\
\hline Sensitivity & $84 \%$ & $78 \%$ & $62 \%$ & & & \\
\hline Specificity & $81 \%$ & $81 \%$ & $84 \%$ & & & \\
\hline Accuracy & $81 \%$ & $80 \%$ & $77 \%$ & & & \\
\hline
\end{tabular}

${ }^{a}$ Paracococcidioides, leprosy, mycobacterial lymphadenitis, inconclusive (no histological changes) neurofibroma, metastasis, and adenoma. 
TABLE 3: Summary of the PCR-positive and PCR-negative results as compared to the other methods used in the protocol to detect tuberculosis in HIV patients

\begin{tabular}{|c|c|c|c|c|c|c|}
\hline & $\begin{array}{l}\mathbf{L}-\mathbf{J}^{\mathbf{a}} \\
\text { Culture }\end{array}$ & $\begin{array}{l}\mathbf{Z N}^{\mathrm{b}} \\
\text { Staining }\end{array}$ & PCR & Histopathology & $\mathbf{N}^{\mathrm{c}}$ & Note: \\
\hline 1 & MTBd & + & + & Avium/Intracelulare complex & 1 & $\begin{array}{l}\text { Possibly misdiagnosed } \\
\text { at histopathology }\end{array}$ \\
\hline 2 & - & - & + & Histoplasmosis & 1 & Co-infection \\
\hline 3 & - & - & + & $\begin{array}{l}\text { Non-specific Lymphadenitis (also reactive } \\
\text { follicular hyperplasia) }\end{array}$ & 6 & Early TB infection? \\
\hline 4 & МTB & - & + & Non-specific Lymphadenitis & 1 & TB \\
\hline 5 & - & - & + & Non-Hodgkin's lymphoma & 1 & Lymphoma + TB \\
\hline 6 & - & + & + & Mycobacterial lymphadenitis & 1 & TB? \\
\hline 7 & мTB & + & + & Inconclusive & 1 & TB \\
\hline 8 & MTB & + & + & Tuberculous lymphadenitis & 5 & TB \\
\hline 9 & МТВ & - & + & Tuberculous lymphadenitis & 3 & TB \\
\hline 10 & - & + & + & Tuberculous lymphadenitis & 2 & TB \\
\hline 11 & - & - & + & Tuberculous lymphadenitis & 6 & TB \\
\hline 12 & - & - & - & Adenoma & 1 & - \\
\hline 13 & - & - & - & Inconclusive (absence of mycobacteria and fungi) & 2 & Inconclusive \\
\hline 14 & - & - & - & Histoplasmosis & 8 & Histoplasmosis \\
\hline 15 & - & - & - & $\begin{array}{l}\text { Non-specific lymphadenitis (Dermatopathic, } \\
\text { Granulomatous lympadenitis, and Reactive } \\
\text { follicular hyperplasia) }\end{array}$ & 30 & Inconclusive \\
\hline 16 & - & - & - & Toxoplasmic lymphadenitis & 2 & Toxoplasmosis \\
\hline 17 & - & - & - & Hodgkin's lymphoma & 6 & \\
\hline 18 & - & - & - & Non-Hodgkin's lymphoma & 4 & \\
\hline 19 & - & - & - & Kaposi's sarcoma & 3 & \\
\hline 20 & - & - & - & $\begin{array}{l}\text { Others (mononucleosis, Lewis lung carcinoma } \\
\text { [LLC], metastatic carcinoma, neurofibroma, } \\
\text { paracoccidiodomicosis) }\end{array}$ & 5 & \\
\hline 21 & - & + & - & Leprosy & 1 & Leprosy \\
\hline 22 & - & - & - & Tuberculous lymphadenitis & 8 & TB \\
\hline 23 & MTB & - & - & Tuberculous lymphadenitis & 1 & TB (false negative PCR) \\
\hline 24 & NTMe & + & - & Tuberculous lymphadenitis & 1 & $\begin{array}{l}\text { NTM (Possibly } \\
\text { misdiagnosed at } \\
\text { histopathology) }\end{array}$ \\
\hline 25 & NTM & - & - & Tuberculous lymphadenitis & 1 & NTM \\
\hline 26 & - & - & - & Inconclusive & 2 & inconclusive \\
\hline
\end{tabular}

a- Lowenstein-Jensen b- Ziehl-Neelsen c- N-number of patients; d- MTB - Mycobacterium tuberculosis, e- NTM - nontuberculous mycobacteria

ded a thorough overview of the potential of these methods, particularly in association with PCR for the diagnosis of TB. For example, two false-negative results were found in the PCR-negative and Ziehl-Neelsenpositive samples; however, when other techniques were used to evaluate these two samples, the picture became clear. In fact, one sample consisted of NTM as confirmed by Lowenstein-Jensen culture, while histopathology diagnosed the other case as lepromatous leprosy that, as expected, did not grow in culture. Therefore, an integrated approach using ZiehlNeelsen, Lowenstein-Jensen culture and histopathology in addition to PCR should increase the sensitivity of the PCR assay by $100 \%$ compared to that achieved when Ziehl-Neelsen and PCR are used alone. Indeed, the use of fresh, whole lymph nodes indicates that the sensitivity achieved in this study is as high as that reported in the literature from studies conducted in the Amazon region to investigate the IS6110 region. An evaluation of PCR in paraffin-embedded ganglions to detect MTB resulted in positivity of only $40 \%$ in Ziehl-Neelsen-positive samples. ${ }^{16}$ When nested PCR was used to identify MTB positivity in skin biopsies of suspected cutaneous TB, PCR positivity in ZiehlNeelsen positive samples was $66 \% .{ }^{15}$ The present results suggest a positivity (sensitivity) of $63 \%$ when compared with a combination of Lowenstein-Jensen culture and histopathology (Table 4). Indeed, PCR 
TABLE 4: Comparison of PCR positivity with the gold standard technique for the diagnosis of tuberculosis, samples testing positive in Lowenstein-Jensen culture or histopathology, in HIV-positive patients with lymphadenitis

\begin{tabular}{cll}
\hline & \multicolumn{2}{l}{$\begin{array}{l}\text { Lowenstein-Jensen culture OR } \\
\text { histopathology }\end{array}$} \\
\hline & Positive & Negative \\
PCR & 19 & 09 \\
Positive & 11 & 65 \\
Negative & $63 \%$ & \\
Sensitivity & $87 \%$ & \\
Specificity & $80 \%$ & \\
Accuracy & & \\
\hline
\end{tabular}

still failed to detect some cases of TB that were only defined at histopathology (8 cases), although these rates are similar to those reported in the literature. ${ }^{15,16}$ Since a conventional, low-cost PCR was used in this study, it is likely that inhibition or even a low detection range of the PCR reaction might be the cause. Optimizing a real-time PCR reaction using primers and probes in this region may improve mean sensitivity rates and also increase detection of resistant forms in multiplex assays. ${ }^{23,24,25}$

Nevertheless, each case should clearly be screened using a wide portfolio of methods in view of the increasing capacity of these techniques to reach a diagnosis. For example, PCR together with culture in Lowenstein-Jensen medium and Ziehl-Neelsen staining was able to detect one case that was misdiagnosed at histopathology. A diagnosis of mycobacterium avium-intracellulare complex is unlikely since PCR and culture in Lowenstein-Jensen medium were positive for TB. A case of co-infection (TB-histoplasmosis) was also found, as well as another case of lymphoma and TB. It is noteworthy that diagnosis following histopathology was inconclusive in 6 cases (non-specific lymphadenitis); however, these samples were PCRpositive. As a matter of fact, three of these six patients were followed up and developed TB after 3-6 months. They were submitted to anti-tuberculosis treatment (ATT) and made a full recovery. In view of these results, it is reasonable to conclude that the use of PCR in fresh samples increased the rates of TB detection (and possibly early HIV-associated TB) in this study and should therefore be implemented as routi- ne practice in laboratories for the diagnosis of lymphadenitis. Indeed, in India, the use of PCR to confirm histopathological findings showed that 3/20 PCR-positive samples could also be considered false-positives; however, following ATT treatment patients made a full recovery. ${ }^{26}$ Moreover, reports from a study conducted in Thailand using paraffin-embedded ganglions from patients with necrotizing non-granulomatous lymphadenitis suggested that PCR was able to detect six positive samples that were not formally included as tuberculosis by any other method. ${ }^{27}$ Taking all these data into consideration, PCR appears capable of successfully diagnosing early cases of TB, which is particularly important considering that extrapulmonary TB is the principal cause of HIV-associated lymphadenitis. Although this protocol is laborious and requires the support of surgical facilities, the combination of histopathological examination, microbiology and PCR assays is extremely robust. The accuracy of PCR was $80 \%$ compared to the combined classical methods for TB diagnosis. The use of this integrated approach that includes PCR to screen patients with lymphadenitis for tuberculosis would help define diagnosis, thus reducing multidrug resistance and therapeutic failure. ${ }^{28,29}$ PCR has been proven to be cost-effective at a Brazilian TB/HIV referral hospital. The costs per correctly diagnosed case were around US\$50 and US\$ 13 for an acid-fast bacillus (AFB) smear plus culture and AFB smear plus PCR dot-blot, respectively. ${ }^{13}$ Therefore, it is highly cost-effective to use PCR as routine practice in a hospital-based molecular pathology laboratory.

In conclusion, these results show that the use of an integrated approach consisting of the implementation of low-cost PCR together with classic microbiological assays and histopathology can significantly improve accuracy in the detection of $M$. tuberculosis infection, enabling treatment to be implemented earlier, improving the quality of life of HIV patients, and reducing the duration of hospital stays, relapses and drug resistance.

\section{ACKNOWLEDGEMENTS}

We would like to acknowledge the collaboration of Reinaldo Dietze from NDI and the help of Lorena Angélica Castano Ramos in the DNA extraction. MOM is a CNPq research fellow. BBB and DZR are in academic training under CNPq fellowships (PROIC-UNL). This project was partially supported by FMTAM grants. 


\section{REFERÊNCIAS}

1. Unaids.org [Internet]. Report on the global AIDS epidemic 2006. [cited 2008 July 0] Available from: http://www.unaids.org/en/KnowledgeCentre/HIVData/ GlobalReport/2006.

2. Metroca CE, Cunninggham-Rundles S, Pollack MS, Sonnabend JA, Davis JM, Gordon B, et al. Generalized lymphadenopathy in homosexual men. Ann Intern Med. 1983;99:583-91.

3. Mohan A, Reddy MK, Phaneendra BV, Chandra A. Aetiology of peripheral lymphadenopathy in adults: analysis of 1724 cases seen at a tertiary care teaching hospital in southern India. Natl Med J India. 2007;20:78-80.

4. Tiwari M, Aryal G, Shrestha R, Rauniyar SK, Shrestha HG. Histopathologic diagnosis of lymph node biopsies. Nepal Med Coll J. 2007;9:259-61.

5. Bekedam HJ, Boeree M, Kamenya A, Liomba G, Ngwira B, Subramanyam VR, et al. Tuberculous lymphadenitis, a diagnostic problem in areas of high prevalence of HIV and tuberculosis. Trans R Soc Trop Med Hyg. 1997;91:294-7.

6. Lönnroth K, Castro KG, Chakaya JM, Chauhan LS, Floyd K, Glaziou P, et al. Tuberculosis control and elimination 2010-50: cure, care, and social development. Lancet. 2010;375:1814-29.

7. Gonçalves MJ, Leon AC, Penna ML. A multilevel analysis of tuberculosis associated factors. Rev Salud Publica (Bogota). 2009;11:918-30.

8. Souza SL, Feitoza PV, Araújo JR, Andrade RV, Ferreira LC. Causes of death among patients with acquired immunodeficiency syndrome autopsied at the Tropical Medicine Foundation of Amazonas. Rev Soc Bras Med Trop. 2008;41:247-51.

9. Uriz J, Reparaz J, Castiello J, Sola J, et al. Tuberculosis en pacientes infectados por el VIH. An Sist Sanit Navar. 2007;30 Supl. 2:131-42.

10. Golden MP, Vikram HR. Extrapulmonary Tuberculosis: An Overview. Am Fam Physician. 2005;72:1761-8.

11. Mert A, Tabak F, Ozaras R, Tahan V, Oztürk R, Aktuğlu Y. Tuberculous Lymphadenopathy in adults: an review of 35 cases. Acta Chir Belg. 2002;102:118-21.

12. API Consensus Expert Committee: API TB Consensus Guidelines 2006: Management of pulmonary tuberculosis, extrapulmonary tuberculosis and tuberculosis in special situations. J Assoc Physicians India. 2006;54:219-34.

13. Scherer LC, Sperhacke RD, Ruffino-Netto A, Rossetti ML, Vater C, Klatser P, et al. Cost-effectiveness analysis of PCR for the rapid diagnosis of pulmonary tuberculosis. BMC infectious Diseases. 2009;9:216.

14. Fujimoto LBM, Salem Jl, Ogusku MM, Ferreira LCL. Avaliação do protocolo PCR4 de Marchetti em tecidos parafinizados para o diagnóstico da tuberculose cutânea e ganglionar. J Bras Patol Med Lab. 2007;43:195-201.

15. Ogusku MM, Salem Jl. Análise de diferentes primers utilizados na PCR visando ao diagnóstico da tuberculose no Estado do Amazonas. J Bras Pneumol. 2004;30:433-9.

16. Behmer OA, Tolosa EMC, Neto AGF. Manual de técnicas para histologia normal e patológica. São Paulo: Edart USP; 1976.

17. Dabbs DJ. Immunohistochemical protocols: back to the future. Am J Clin Pathol. 2008;129:355-6

18. Ministério da Saúde. Secretaria de Políticas de Saúde. Coordenação Nacional de DST e Aids. Tuberculose: diagnóstico laboratorial: baciloscopia. Brasília: Ministério da Saúde; 2001. 70 p.
19. Ministério da Saúde do Brasil. Secretaria de Vigilância em Saúde. Centro de referência Professor Hélio Fraga. Manual de Bacteriologia da Tuberculose. 3. ed. Rio de Janeiro: Centro de referência Professor Hélio Fraga; 2005. 240 p.

20. Martinez AN, Britto CF, Nery JA, Sampaio EP, Jardim MR, Sarno EN, et al. Evaluation of real-time and conventional PCR targeting complex 85 genes for detection of Mycobacterium leprae DNA in skin biopsy samples from patients diagnosed with leprosy. J Clin Microbiol. 2006;44:3154-9.

21- Boffo MMS, Mattos IG, Ribeiro MO, Neto ICO. Tuberculose associada a AIDS características demográficas, clínicas e laboratoriais de pacientes atendidos em um serviço de referência do sul do Brasil. J Bras Pneumol. 2004;30:140-6.

22. Martins Junior EV, Marques BP, Reis Neto ET, Lima BCMLS, Neumann YRB. Tuberculose cutânea disseminada com escrofuloderma associado à tuberculose de arco costal. An Bras Dermatol. 2007;82:343-7.

23. Helb D, Jones M, Story E, Boehme C, Wallace E, Ho K, et al. Rapid detection of Mycobacterium tuberculosis and rifampin resistance by use of on-demand, near-patient technology. J Clin Microbiol. 2010;48:229-37.

24. Min JW, Yoon HI, Park KU, Song JH, Lee CT, Lee JH. Real-time polymerase chain reaction in bronchial aspirate for rapid detection of sputum smear-negative tuberculosis. Int J Tuberc Lung Dis. 2010;14:852-8.

25. Roselino AM. Biologia molecular aplicada às dermatoses tropicais. An Bras Dermatol. 2008;83:187-203.

26. Chawla K, Gupta S, Mukhopadhyay C, Rao PS, Bhat SS.PCR for M. tuberculosis in tissue samples. J Infect Dev Ctries. 2009;3:83-7.

27. Nopvichai C, Sanpavat A, Sawatdee R, Assanasen T, Wacharapluesadee S, Thorner PS,et al. PCR detection of Mycobacterium tuberculosis in necrotising nongranulomatous Iymphadenitis using formalin-fixed paraffin-embedded tissue: a study in Thai patients. J Clin Pathol. 2009;62:812-5.

28. Bammann RH, Zamarioli LA, Pinto VS, Vázquez CM, Litvoc MN, Klautau GB, et al High prevalence of drug-resistant tuberculosis and other mycobacteria among HIVinfected patients in Brazil: a systematic review. Mem Inst Oswaldo Cruz. 2010;105:838-41

29. Zamarioli LA, Coelho AG, Pereira CM, Ferrazoli L, Bammann RH. Laboratory identification of mycobacteria in respiratory samples from HIV-positive patients suspected of tuberculosis. Rev Soc Bras Med Trop. 2009;42:290-7.

ENDEREÇO PARA CORRESPONDÊNCIA / MAILING ADDRESS: Sinésio Talbari

Av. Pedro Texeira, 25 - Dom Pedro 69040-000 Manaus, Amazonas, Brazil. E-mail: sinesiotalhari@terra.com.br 